\title{
HYBRID DERIVATIVES IN CONTEMPORARY KOREAN
}

\author{
ANNA BOROWIAK
}

\begin{abstract}
The advances in international and intercultural communication resulting in the multilingualism of native communicative communities and ultimately leading to the creation of the global communicative community, is well reflected in the lexical subsystem of many languages all around the world. This subsystem is continuously being enriched not only with numerous borrowings but also with the formations of hybrid type. As far as the Korean language is concerned, opening of the Korean borders to the world in 1876, also opened 'the lexicon borders' to the considerable number of Western loanwords, which, with time, started to be used in morpheme-based word-formation processes such as derivation and composition, as well as in new word-formation processes - among them blending and reanalysis. Despite the fact that there are two types of hybrid derivatives distinguished according to the origin of their counterparts (roots and affixes), which are coined and used in contemporary Korean, this article, given its scope, focuses only on the derivatives having the Koreanized bases of European provenance.
\end{abstract}

Key words: hybrid derivatives, Korean, adjectivization, verbification, nominification

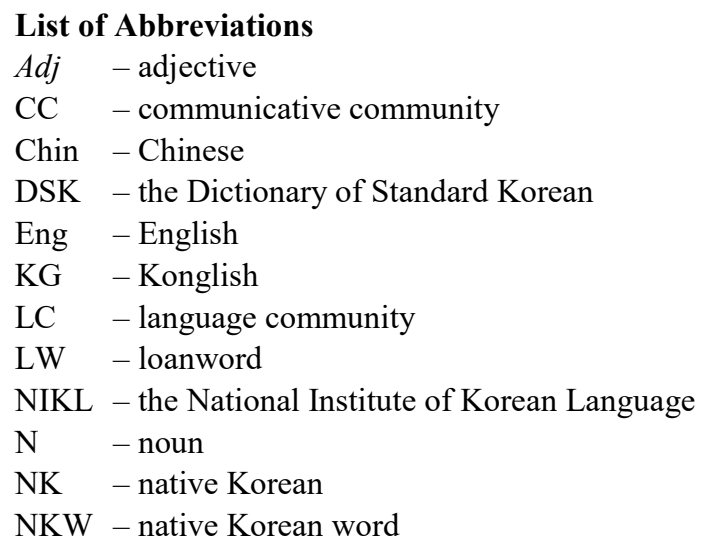




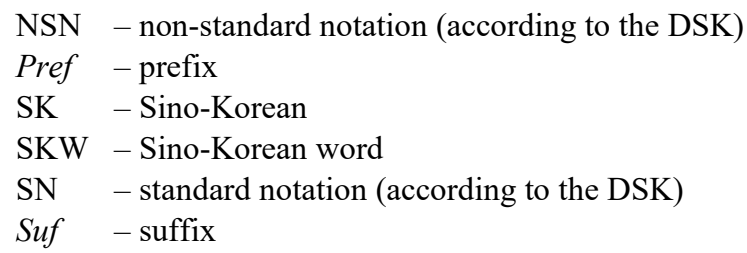

\section{List of Symbols}

[+] - neologism noted in the DSK

$[-] \quad-$ neologism not noted in the DSK

$\{2000\}$ - year in which the coinage was introduced to the Korean lexicon (data taken from the DSK), no date means that the word might be noted in the DSK but there is no record concerning the beginning of its usage in Korean

\section{Introduction}

Word-formation processes not only reflect the continuous and unavoidable changes in non-lingual reality as far as the cultural, social, economic and technological aspects are concerned, but they also confirm the advances in international and intercultural communication. This communication, following the theory of communicative communities proposed by Zabrocki (1963: 9-33), results in the multilingualism of native CCs and ultimately leads to creation of the global CC.

Lexical subsystem, as the most open on the semantic plane, witnesses to the expansion of the global communication by widely manifesting itself through numerous borrowings in languages all around the world. Korean is not an exception although Korea was able to protect its national language from borrowings thanks to pursuing the policy of isolation through rejecting the international contacts until the $19^{\text {th }}$ century. As a consequence, the country has been referred to as the Hermit Kingdom by Elliot Griffis (1894), Bird Bishop (1897) and others Western scholars. The gradual opening of the Korean borders to the world though, as a result of the so-called gunboat diplomacy and signing the Kanghwa Treaty in 1876, referred to by Connor (2009: 39) as 'the first unequal treaty with an imperialist power', Korea underwent enormous socio-economic changes, which have also influenced the language itself, enforced with the necessity of communication with the West. The lack of lingual equivalents denoting the creations of Western civilization from both professional and cultural fields such as medicine, architecture, economy, politics as well as cuisine, music and sports, have paved the way for numerous borrowings which firstly came indirectly through Japanese and later directly from English, and with time from other European languages, among them French, German, Italian, Portuguese and Russian. ${ }^{1}$

\footnotetext{
${ }^{1}$ E.g. (i) 택시 taeksi - a taxi, 메르스 mereuseu - MERS (from English); (ii) 레스토랑 reseutorang - a restaurant, 푸아그라 puageura - foie gras (from French); (iii) 아르바이트 areubaiteu - a part-time
} 
As a consequence, in the Korean lexicon previously consisting only of:

(i) the Sino-Korean words (Kor 한자어, hanjaeo) ${ }^{2}$ and

(ii) the Korean indigenous words (Kor 고유어, goyueo),

(iii) the sub-lexicon of borrowings (Kor 외래어, oeraeeo) was created. ${ }^{3}$

The last two decades or so show, that the influx of borrowings stands behind the formation of the fourth sub-lexicon - hybrids, referred to in Korean as honjongeo (Kor 혼종어). ${ }^{4}$ The coexistence of the above-mentioned sub-lexicons has resulted in the creation of many synonymic doublets or even triplets. ${ }^{5}$ Lee et al. (2011: 302) point out that '[t]hroughout the known history of Korean, Sinitic vocabulary has tended to displace native words. (...) whenever Sino-Korean synonyms exist along-

job, 알츠하이머 alcheuhaimeo - Alzheimer (from German); (iv) 오페라 opera - an opera, 첼로 chello - a cello (from Italian); (v) 카포에라 kapoera - capoeira, 카스텔라 kaseutella - castella [a sponge cake] (from Portuguese); (vi) 마트료시카 mateuryosika - a matryoshka, 빨치산 ppalchisan - a partisan (from Russian).

${ }^{2}$ Song (2005: 83) points out 'many of these (...) words were either coined on the basis of Koreanized Chinese characters or created in Japan from Chinese characters and then borrowed into Korean'. He also emphasizes (cf. p. 85), that SKWs have been a part of Korean for so long (they have been introduced as early as 108 B.C. when Han China took control over most part of the Korean Peninsula), that Koreans do not regard them as loanwords, despite the fact that they are being referred to in Korean as 'Chinese words' as opposition to 'foreign words' coming from e.g. English, German etc., (cf. p. 84). Choo et al.(2008: 85) convince that most of the SKWs are perceived 'to be fully "Korean"', since they were borrowed before 1945. That is why, following Song (2005: 83-84) '[a]rguing that SinoKorean words are loanwords is like arguing that English words based on Latin and Greek elements are loanwords.' The SKWs are so firmly established in Korean, that 'it may not be appropriate to view them as loanwords, albeit based on Chinese characters.'

${ }^{3}$ Huszcza (2011: 118) apart from the NKWs and SKWs constituting the Korean lexicon distinguishes xeno-Korean words, by which he means foreign words most notably of English origin.

${ }^{4}$ As far as the structure of the Korean lexicon is concerned according to Song (2005: 83) slightly over $52 \%$ of Korean words are said to be of SK stock, while over $42 \%$ are of NK one. The rest $-6 \%$ are LWs, coming mostly from English. Lim et al. (2005: 205) on the basis of the DSK (Kor 표준국어대사전, pyojungugeodaesajeon) presents different statistics, despite the fact that both books were published in the same year. According to the second research $25.9 \%$ are NKWs, $58.5 \%$ SKWs, 4.7\% LWs and 10.9\% are hybrids. Sohn (2001: 87) and Choo et al. (2008: 85) give slightly different statistics. According to them about $35 \%$ are of NK stock, about $60 \%$ 'can be traced to Chinese', which means that LWs constitute about 5\% of the Korean lexicon. Kim et al. (1999: 342) recalling two researches published in 1957 and in 1961 indicate, that the ratio between NKWs, SKWs and LWs is 46: 52: 2 and 25: 69: 6 respectively. Regardless of the exact figures, the statistics show, that the number of LWs is growing. It is worthy to note, that although Lim et al. (2005: 205) do mention the existence of hybrids, they do not propose the quadruple division of the lexicon. Nonetheless, since the number of hybrids is constantly growing distinguishing the fourth sub-lexicon is reasonable and justified.

${ }^{5}$ E.g. (i) 'wife' - NKW anae (Kor 아내), SKW buin (Kor 부인; Chin 夫人, füren), LW waipeu (Kor 와이프), (ii) 'dance' - NKW chum (Kor 춤), SKW muyong (Kor 무용; Chin 舞踊, wǔyǒng), LW daenseu (Kor 댄스). 
side native words, the Sino-Korean words are generally considered as more elegant, and therefore sometimes serve as respectful, even honorific terms.' Choo et al. (2008: 89) notice, that LWs 'are generally associated with a more modern version of a [particular] concept', which would explain the tendency to prioritize the usage of foreign words over the NK ones. Choo et al. also indicate (cf. p. 85) that sometimes the SKWs 'take on a more specialized and narrower meaning'. In fact, NKWs in comparison to SK ones are considered to be more colloquial, and as such are used in everyday conversation.

In relation to the neologisms, Lim et al. (2005: 201) referring to the research conducted each year by the NIKL, point out that since the middle 1900 every year about 1500-1600 new words have been coined, in 2000 the number has doubled (it was about 2947 words), since then the number reaches about 3000 new words per year. We may presume that two decades later the number is even bigger. Jeon et al. (2007: 48) using the quantitative method to analyze new coinages in the Korean lexicon notice, that $36.4 \%$, of the words coined between 2002 and 2004 have foreign origin, about $32.5 \%$ are hybrids, and $26 \%$ are SKWs. Is means that only $5.1 \%$ of the new coinages are in fact words of NK stock. This data shows the gravity of the situation, which may become even more serious given the fact that the research was published 13 years ago. One can only hope, that the situation has improved in favor of the NK stock. Furthermore, Song (2005) indicates that there are over 20000 LWs in Korean, $90 \%$ of which are of English stock. Since then 15 years have passed and the number of borrowings has risen for sure. Ko (2014: 54) while discussing the subject of the $20^{\text {th }}$ century neologisms emphasizes that among relatively globally wellknown languages it is difficult to find a language, which would undergo during the last century so many changes as the Korean language has had.

Considering the fact that English has already established its status as a lingua franca and the close cooperation between South Korea and the US especially after the Korean War (1950-1953), it is not a surprise that English is perceived as the language having the biggest influence on the lexicon of the Contemporary Korean. Yet it is not just words that are being borrowed, since there is a growing number of new coinages formed from Koreanized English bases ${ }^{6}$ or other elements, often re-

\footnotetext{
${ }^{6}$ Despite the fact that there are some discrepancies concerning the definition of terms used within the field of morphology such as root, stem and base, for the sake of terminological transparency in this research the term stem as concerning inflectional morphology and being 'the part of the word-form which remains when all inflectional affixes have been removed' (cf. Bauer 1983: 20) will not be used. The term base will be used in order to indicate, following Bauer (1983:21), 'a derivationally analyzable form to which derivational affixes are added', while root as 'a form which is not further analyzable, either in terms of derivational and inflectional morphology, (...) a part of a word-form that remains when all inflectional and derivational affixes have been removed (...) as a basic part always present in a lexeme'. In other words, following Plag (2003: 11), in all cases where the status of a form as indivisible is not at issue, the term 'base' or base word will be used. Consequently, following the above explanation the word untouchable consists of the root or unanalyzable base touch-and the derivational suffix
} 
ferred to as Konglish (Kor 콩글리 시, konggeullisi), which are also used in the present-day word-formation, so are new word-formation processes such as blending and reanalysis ${ }^{7}$ previously not observed and discusses in researches devoted to the Korean word-formation field. All of the above not only reveals and confirms the influence the global $C C$ exerts on Korean, but it also shows the creativity of Korean native speakers as far as word coining is concerned.

The main objective of this article is to examine the youngest but rapidly expanding sub-lexicon of the Korean language namely - the hybrid sub-lexicon, in order to answer the question concerning the extent of hybridization on neologisms in Contemporary Korean. Due to the scope of this article however, this research will focus only on the derivatives having bases of foreign (most notably English) provenance. In order to answer the above question, the author will:

(i) identify the newly coined hybrid derivatives,

(ii) analyze their structure and semantic properties,

(iii) investigate whether they have already become the dictionary entries.

Consequently, this research will focus on:

(i) the adjectivization and verbification, as well as

(ii) the nominification of LWs.

The former unlike the latter apart from the graphemic adaptation to Korean also requires the grammatical adaptation which is generally accomplished with the help of the same SK Suf-hada (Kor -하다), that is why the adjectivization and verbification will be discussed together. ${ }^{8}$

For the sake of bigger transparency and bearing in mind that the readers (either the researchers or students) may not know the Korean alphabet - Hangeul, every Korean term or example will be given along with its Romanization. Author has decided to use the Romanization method introduced in 2000 by the Ministry of Culture

-able, which with touch forms an analyzable or derivative base (touchable) of the prefixal derivative untouchable.

${ }^{7}$ Hamans (2015: 159-181) notices that the 'global language contact may lead to the borrowing of linguistic processes' - this happens also in Korean. For more information on reanalysis see Hamans et al. (2009) and Haspelmath (1995), for the discussion concerning the corresponding concepts e.g. confusivum and difusivum see Zabrocki (1980) and semi-morphemic element see Marchand (1966).

${ }^{8}$ Korean linguists do not have unanimous opinion concerning the status of -hada. Some of them (cf. Koh 1999) perceive it as a root meaning 'to do', while others (cf. Shim 1982, Kim 1996, Kim 2009) as a derivational suffix. In this research however, -hada is considered the latter, and consequently words with -hada are treated as derivatives. It is worth emphasizing though, that from the European grammar point of view -hada as well as -seureopda (cf. ex. (3.5)-(3.6)) can rather be treated as a kind of auxiliaries, given their ability to take various endings indicating e.g. honorification or tense, which differs them from suffixes deriving other parts of speech. 
Sports and Tourism and currently used in the Republic of Korea and in many countries around the world. Since the new hybrid coinages do not have a long history in Korean due to the fact that they have been coined recently, some of them are still not listed as dictionary entries in the biggest online DSK provided by the NIKL ${ }^{9}$. Nonetheless, for they are being used in everyday conversation, press articles, TV shows and widely understood Internet communication especially popular among the younger generation, it allows us to assume, that with time also the rest of them might be noted in dictionaries, unless language purists will convince the Korean native speakers to use their NK equivalents instead.

\section{The growing presence of LWs in word-formation processes in Korean}

The number of borrowings present in the lexicon of Contemporary Korean is rapidly growing and so is their presence in word-formation processes, in which hybrid derivatives and hybrid compounds ${ }^{10}$ are being coined. The majority of easily noticeable borrowings are internationalisms, coming from various semantic fields - especially from the domains of economy, politics, medicine, technology, pop culture, social reality etc., and can be perceived, following Bloomfield's nomenclature (1933: 458), as cultural borrowings, which as he explains 'show us what one nation has taught another'. Some of their examples were already presented in the $1^{\text {st }}$ footnote (cf. p. 2).

LWs in order to be used in the Korean language, as illustrated in the abovementioned examples, have to undergo the process of Koreanization, meaning the graphemic and phonological assimilation. ${ }^{11}$ In case of the inflected words (verbs and adjectives) though, the grammatical adaptation is also mandatory. ${ }^{12}$ In this process

\footnotetext{
${ }^{9} \mathrm{Cf}$. https://opendict.korean.go.kr/main (accessed 2019-03-21).

${ }^{10}$ The latter can be divided into true hybrid compounds and quasi-hybrid compounds (cf. Borowiak 2019).

${ }^{11}$ Sometimes though borrowing results in the creation of homonymic pairs as (i) hil (Kor 힐) standing for 'heel' and 'hill' and (ii) seil (Kor 세일 ) standing for 'sale' and 'sail' exemplify.

12 'A word which has been transferred from one language into another is itself subject to the interference of the grammatical, as well as phonic system of the recipient language' (Weinreich, 1953: $44)$, where the complete non-adaptation as well as full grammatical integration of a word can be found (cf. p. 46). The choice however, whether to integrate the transferred words or not, is made by the speakers. 'In case of simple lexical elements [transferred in unanalyzable form], the most common type of interference is the outright transfer of the phonemic sequence from one language to another' (cf. p. 47). Nonetheless, since Korean has its own script called Hangeul, every single word borrowed from languages using e.g. the Latin alphabet or Chinese characters, the graphemic adaptation has to accompany the phonological and grammatical ones. In this context it is worthy to note, that in order to borrow foreign words from languages using the Latin alphabet some rules, according to which they
} 
LWs are also assigned to the respective word class distinguished in Korean, thanks to which they can perform syntactic functions in a sentence. Consequently, taeksi (Kor 택시) denoting 'a taxi' is assigned to the class of nouns, as a consequence of which it can take particles and perform the role of the subject, the object etc. The obligatoriness of the grammatical adaptation of verbs and adjectives results from the fact that all borrowings are treated as indeclinable words in Korean, and thus in order to take conjugation endings and to perform the role of e.g. the predicate or the attribute they have to undergo the above-mentioned grammatical adaptation. In other words, from the word-formation point of view, when adjectives (in their source language) are borrowed, they are treated as bound or incomplete roots (Kor 불완전 어기, bulwanjeon eogi), which means they are not adjectives in Korean. ${ }^{13}$ In fact, they do not belong to any of the nine word-classes distinguished in Korean and thus they cannot be combined neither with particles (as nominals do) nor with inflectional endings (as adjectives and verbs do). In order to receive the status of an adjective in Korean, as it is e.g. in case of peuropesyeoneol (Kor 프로페셔널) - the Koreanized English adjective 'professional', it has to be combined with the NK Suf -hada (Kor -하다). The hybrid derivative peuropesyeoneolhada (Kor 프로페셔널하다) meaning 'to be professional' formed in the process of adjectivization can be used as other NK adjectives.

Despite the fact that borrowed nouns do not have to undergo nominification in order to be used in Korean, Koreanized nouns relatively often take part in derivation and compounding, contributing to the increase in the number of hybrids, which are eagerly used especially by the younger generations of Koreans in blogs, chats, TV programs and articles. Among the hybrid formations apart from nouns there are also verbs and adjectives. Nonetheless, the category of adjectives has the most numerous representations judging by the fact they are much easier to be noticed, in comparison to the other two classes of words. Of course, statistical analysis should be done in order to confirm this assumption.

\section{Adjecivization and verbification}

Among the hybrid coinages used in Contemporary Korean are adjectives and verbs derived from words of foreign origin, which as the examples (3.1)-(3.4) show, in their source language are either:

could be written in Korean alphabet had to be made. Lim (1996: 28) and Kang (2017: 425) point out that the rules concerning the orthography of LWs (Kor 외래어 표기법, oeraeeo pyogibeop) were firstly introduced in 1933 by the Korean Language Society (Kor 조선어 학회, Joseoneo Haghoe at that time) as a part of the set of orthographic rules of Korean. In 1940 the same society revised them. Since then the rules have been revised many times. For detailed discussion on this subject refer to Lim (1996) and Kang (2016: 419-492).

${ }^{13}$ Perceiving words of foreign origin as roots in Korean was also noticed by Kim (2008: 194). 
(i) simple words such as common nouns (cf. (3.4.2)), proper nouns (cf. (3.4.1)) or adjectives (cf. (3.1.2) and (3.1.4)),

(ii) derivatives (cf. (3.1.1), (3.1.3), (3.1.5), (3.2.1)-(3.2.2) and others) or

(iii) compounds (cf. (3.2.5) and (3.3.1)-(3.3.5)).

All of these formations underwent grammatical adaptation to Korean through the processes of adjectivization and verbification, with the help of the most productive NK Suf-hada (Kor -하다). That is why, it is not a surprise that hybrid derivatives with -hada are so numerous in Contemporary Korean.

Kim (2008: 194) correctly notices that the majority of foreign verbs, which have entered the Korean lexicon, have the structure ' $\mathrm{N}+$-hada', while foreign adjectives 'root $+-h a d a$ '. Some examples of hybrid adjectives and hybrid verbs are presented below (cf. (3.1)-(3.2) and (3.3)-(3.4) respectively). In order to indicate the predicatification of Koreanized adjectives, they will be translated into English as nominal predicates having the structure 'to be $A d j$ '.

(3.1) Adjective derivatives with NK Suf-hada (Kor -하다) as dictionary entries

(3.1.1) 프로페셔널하다 peuropesyeoneolhada - to be professional, [+], [SN], $\{2011\}$

(프로페셔널 peuropesyeoneol-professional),

(3.1.2) 스마트하다 seumateuhada - to be smart, [+], [SN], \{-\}

(스마트 seumateu-smart),

(3.1.3) 로맨틱 하다 romaentikhada-to be romantic, [+], [SN], \{-\}

(로맨틱 romaentik - romantic),

(3.1.4) 큐트하다 kyuteuhada - to be cute, [+], [SN], \{2011\}

(큐트 kyuteu - cute),

(3.1.5) 빈티지하다 bintijihada - to be vintage, [+], [SN], \{2003\}

(빈티지 bintiji-vintage),

(3.1.6) 쿨하다 kulhada - to be cool, [+], [SN], \{2011\}

(쿨 $k u l-$ cool).

(3.2) Adjective derivatives with NK Suf-hada (Kor -하다) not listed as dictionary entries

(3.2.1) 글래 머러 스하다 geullaemeoreoseuhada - to be glamorous, [-], $[-],\{-\}$

(글래 머러 스 geullaemeoreoseu-glamorous),

(3.2.2) 드랜 디하다 deuraendihada - to be trendy, [-], [-], \{-\}

(드랜 디 deuraendi-trendy),

(3.2.3) 에스테틱 하다 eseutetikhada-to be aesthetic, [-], [-], \{-\}

(에스테틱 eseutetik-aesthetic),

(3.2.4) 샤이니하다 syainihada - to be shiny, [-], [-], \{-\}

(샤이니 syaini - shinny), 
(3.2.5) 판타스틱 하다 pantaseutikhada - to be fantastic, , [-], [-], \{-\} (판타스틱 pantaseutik - fantastic).

(3.3) Verb derivatives with NK Suf-hada (Kor -하다) as dictionary entries

(3.3.1) 다운로드하다 daunlodeuhada - to download, [+], [SN], \{1996 $\}^{14}$ (다운로드 daunlodeu - a download),

(3.3.2) 로그인하다 logeuinhada - to log-in, [+], [SN], \{2003\} (로그인 logeuin - a login),

(3.3.3) 업 데이트하다 eopdeiteuhada - to update, [+], [SN], $\{-\}$ (업 데 이드 eopdeiteu - an update),

(3.3.4) 업 그레이드하다 eopgeureideuhada - to upgrade, [+], [SN], \{-\} (업 그레이드 eopgeureideu - an upgrade),

(3.3.5) 다운그레이드하다 daungeureideuhada - to downgrade, [+], [SN], $\{2010\}$

(다운그레이드 daungeureideu - a downgrade). ${ }^{15}$

(3.4) Verb derivatives with NK Suf -hada (Kor -하다) not listed as dictionary entries

(3.4.1) 구글하다 gugeulhada - to surf the Web using Google search device, $[-],[-],\{-\}$

(구글 gugeul - Google (an American technology company providing Internet-related services and products)),

(3.4.2) 셀 카하다 selkahada - to take a selfie, [-], [-], $\{-\}$

(셀 카 selka- a selfie).

It is worth pointing out, that all of the coinages exemplified in the above (3.3) come from the IT sector and are in fact compound nouns in English. ${ }^{16}$ Some of them (cf. (3.3.4) and (3.4.2)) even have their abbreviated forms - which are yet another example of Konglish. The former eopgeul (Kor 업 글) meaning 'an upgrade' ([+], [NSN], \{2012\}) despite its NSN, has already became the root of a compound noun eopgeulbyeong (Kor 업글병, [+], [-], \{-\}) meaning 'an upgrade disease', where byeong (Kor 병, Chin 病) denotes a disease. This coinage indicates an attitude of

\footnotetext{
14 The Ministry of Culture, Sports and Tourism in notification No. 1996-13 issued in 1996 proposed as an element of the language purification policy to replace the words of foreign origin with their NK equivalents, which applies to examples given at (3.3.1) (3.3.3) - naeryeobadgi, gyeongsin and hyangsang (Kor 내려받기, 경신, 향상 respectively (cf. https://opendic.korean.go.kr/dictionary/view? sense_no=596822\&viewType=confirm accessed 2019-11-19). Since the example (3.3.4) was borrowed relatively not long ag0 it is not listed among the NK equivalents.

${ }^{15}$ Instead of -hada generally deriving transitive verbs from nominal bases, as shown in (3.3), another suffix -doeda (Kor -되다) conveying the meaning of 'to become/ be/ get N' and deriving passive verbs, can also be used (cf. also (4.9)-(4.10)).

${ }^{16}$ Bernard (2004: 530) treats words such as 'to downgrade', 'to outsource' etc. as compound verbs, we may presume then that 'a downgrade' and 'an upgrade' are compounds too.
} 
somebody who tends to buy new cellphones or other electronic devices as soon as they are released onto the market. The second example given at (3.4.2) - selka (Kor 셀 카) is a blend from selpeu kamera (Kor 셀프 카메라) designating 'a self-camera'. The existence of these examples makes one realize not only how productive the NK Suf -hada really is, but also that foreign words apart from simply being borrowed and Koreanized may also take an active part in other word-formation processes among them blending which, as already-mentioned, is a relatively new process in Korean.

Apart from -hada there is another very productive NK Suf-seureopda (Kor - 스럽 다). It conveys the meaning of 'possessing the qualities of N / to be N-ous', where $\mathrm{N}$ indicates the features of the base. Unlike -hada though it derives only adjectives. ${ }^{17}$ Nonetheless, the Internet-based research has revealed that this productive suffix in a very few cases is actually used to assimilate LWs to Korean. Among these hybrid adjectives are words derived from proper nouns - names of people or popular brands (cf. (3.5)) and common nouns (cf. (3.6)). None of them though can be found in the DSK or any Korean language dictionary for that matter.

Adjectives derived with NK Suf-seureopda (Kor -스럽다) from proper nouns

(3.5.1) 오바마스럽다 obamaseureopda - to be cool/ splendid, etc. [-], $[-],\{-\}^{18}$

(오바마 obama-Obama (the $44^{\text {th }}$ president of the United States)),

구찌스럽 다 gujjiseureopda - to be superb/ excellent/ splendid [-], $[-],\{-\}^{19}$

(구찌 gujji - Gucci (an Italian luxury brand for fashion and leather products)),

${ }^{17}$ Another property differentiating these two suffixes is that -hada performs only the derivational or strictly formal function in adjectives and does not convey semantic meaning, while -seureopda does. According to Lee (1983: 183) and Kim (1996: 177) the latter designates 'closeness' to the meaning indicated by the root when used attributively.

${ }^{18}$ Despite the fact that neither the DSK nor any other dictionary has this adjective as its entry, it is possible to find the record of its wide usage in 2009 in mass media from that time. 'The Korea Times', 'Meail Business Newspaper', 'YTN News', 'SBS News' and others introducing the word explain its meaning with an exemplary sentence - namely 'You are so Obama.' (Kor 너는 참 오바마스럽다. neoneun cham obamaseureopda) meaning 'You are so cool.' (cf. http://sf.koreatimes.com/article/20090 803/539688, accessed 2019-11-18, https:/www.mk.co.kr/news/world/view/2009/08/415606/, accessed 2019-11-18 and https://www.ytn.co.kr/_ln/0104_200908031041141257, accessed 2019-11-18, https://news. sbs.co.kr/news/endPage.do?news_id=-N1000625918 accessed 2019-11-18).

${ }^{19}$ Although dictionaries do not mention the existence of this hybrid derivative, its meaning is explained as it is in case of (3.5.1) in Korean media, according to which it means 'to be excellent, superb, splendid, beautiful, fine’ (Kor 멋지다, meotjida) (cf. http://media.fastcampus.co.kr/knowledge/dgn/ux gucci/, https://www.insight.co.kr/news/211343, accessed 2019-11-18). The latest posts and news where it can be found were published in Feb. 2019 and they were used mainly by the younger generation of Koreans. 
(3.5.3) 애플스럽다 aepeulseureopda - to be unique from the design or function point of view but rather expensive ${ }^{20}$

(애플 eapeul - Apple (an American technology company)),

(3.5.4) 잡스스럽다 jabseuseureopda - to be like Jobs, to be enthusiastic about something (잡스 jabseu - surname of Steve Jobs (the founder of Apple Inc.)). ${ }^{21}$

(3.6) Adjectives derived with NK Suf-seureopda (Kor -스럽 다) from common nouns

(3.6.1) 커플스럽 다 keopeulseureopda - to be like a couple ,[-], [-], \{-\}, (커플 keopeul - a couple)

(3.6.2) 글래 머스럽다 geullaemeoseureopda - to be glamorous, [-], $[-],\{-\}$,

(글래 머 geullaemeo-glamor). ${ }^{22}$

\section{Nominification}

The bases of foreign provenance there also used to derive suffixal and prefixal nouns. The former though are more numerous, as this chapter will illustrate. Accordingly, the nominification takes place with the help of both SK and NK suffixes. Among SK suffixes are: -nam (Kor -남, Chin -男) and -nyeo (Kor -녀, Chin -女) standing respectively for 'a male' and 'a female'; - $h w a$ (Kor -화, Chin -化) indicating 'a process' or 'a change' and conveying the meaning of -ization; -gwang (Kor -광, Chin 狂) denoting 'an enthusiast of N' and -jang (Kor -장, Chin 場) indicating 'a place'. Among the NK suffixes are: - jaengi (Kor - 쟁이) 'a man who does $\mathrm{N} /$-er' and -kkun (Kor - 꾼) denoting 'a man noted for N/ a man occupied with N'. Although the statistic research would be crucial in order to make any assumptions, the below examples confirm that the SK suffixes are used more frequently in comparison to the NK ones. Consider the following examples:

${ }^{20} \mathrm{Cf}$. https://deskgram.cc/explore/tags/애플스럽다, https://www.clien.net/service/board/park/854114 (accessed 2019-11-18).

${ }^{21}$ Adjectives given at (3.5.3) and (3.5.4) were also used in the book about Steve Jobs titled '포스트 잡스, 잡스가 멈춘 곳에서 길을 차다' written by 김동준 and김재범, published in Seoul in 2011 by JS Gonggan.

${ }^{22}$ The suffix -seureopda at the beginning the $18^{\text {th }}$ century was used to derive denominal adjectives from consonant-rhyme bases. Its productiveness has grown over time and nowadays it is used with vowel-rhyme bases as well (cf. Kim 2005: 134-135). Lee (2009: 163) perceives the natural ability of -seureopda to join with bases of foreign origin, among them proper nouns, as a confirmation that it is widening its scope of usage. Nonetheless, he provides only two examples - bawensaseureopda (Kor 바웬사스럽 다) and intelseureopda (Kor 인텔스럽 다), where the first base is the surname of the former Polish president Wałęsa, and the second one a company's name - Intel. In fact, none of these examples is noted in dictionaries or online mass media. 
(4.1) Noun derivatives with SKSuf-nam (Kor -남, Chin - 男) 'a male'

(4.1.1) 싱글남 singeulnam - a single man, an unmarried man, [+], [SN], $\{2010\}$

(싱글 singeul-(a) single) $)^{23}$,

(4.1.2) 댄디남 daendinam - a dandy man, an elegant man, [+], [SN], $\{2008\}$

(댄디 daendi-(a) dandy),

(4.1.3) 마초남 machonam - a macho, [+], [NSN], \{2009\}

(마초 macho - (a) macho),

(4.1.4) 매너남 maeneonam - a well-mannered man, [+], [SN], \{2010\}

(매너 maeneo - (a) manner(s)),

(4.1.5) 미팅남 mitingnam - a man that somebody is having a blind date with, [+], [SN], $\{2008\}$

(미팅 miting - a meeting (used in Korean as the equivalent of 'a blind date')),

(4.1.6) 사이다남 saidanam - a man who easily deals with (a) frustrating situation(s) as if he were drinking a cider, [+], [SN], $\{2015\}$

(사이다 saida-cider),

(4.1.7) 터프남 teopeunam - a tough man/guy, [+], [NSN], \{2011\}

(터프 teopeu - tough),

(4.1.8) 섹 시남 seksinam - a sexy man, $[-],[-],\{-\}$

(섹 시 seksi-sexy).

(4.2) Derivatives with SK Suf-nyeo (Kor -녀, Chin -女) 'a female'

(4.2.1) 싱글녀 singeulnyeo - a single woman, an unmarried woman [+], [SN], $\{2010\}$

(싱글 singeul - (a) single),

(4.2.2) 마초녀 machonyeo - a female macho, [-], [-], \{-\}

(마초 macho - (a) macho),

(4.2.3) 매너녀 maeneonyeo-a well-mannered woman, [+], [SN], \{2007\} (매너 maeneo - (a) manner(s)),

(4.2.4) 미팅녀 mitingnyeo - a woman that somebody is having a blind date with, [+], [SN], $\{2010\}$

(미팅 miting - a meeting (used in Korean as the equivalent of 'a blind date')),

(4.2.5) 사이다녀 saidanyeo - a woman who easily deals with (a) frustrating situation(s) as if she were drinking a cider, [+], [SN], $\{2015\}$

(사이다 saida-cider),

\footnotetext{
${ }^{23}$ Apart from singeulnam its synonym - sollonam (Kor 솔로남) also derived from the word of foreign origin, namely solo (Kor 솔로) meaning 'solo' is used as well ([+], [SN], \{2011\}).
} 
(4.2.6) 터 프녀 teopeunyeo - a tough woman, [+], [NSN], \{2009\}

(터 프 teopeu - tough),

(4.2.7) 섹 시녀 seksinyeo - a sexy woman, [+], [SN], \{2004\}

(섹 시 seksi-sexy).

As the above examples (4.1)-(4.2) illustrate, numerous hybrid nouns have already become dictionary entries. These new coinages are especially eagerly used by the younger generations of Koreans. As far as their bases are concerned, with the exception of '(a) manner(s)' (cf. (4.1.4), (4.2.3)), 'a meeting (cf. (4.1.5), (4.2.4)) and 'a cider' (cf. (4.1.6), (4.2.5)), they are homographs, which may function in English as:

(i) nouns or adjectives (cf. (4.1.1)-(4.1.3), (4.2.1)-(4.2.2)),

(ii) nouns, adjectives or adverbs (cf. (4.1.7) and (4.2.6)).

Apart from the above-mentioned homographs there are roots such as e.g. 'sexy' seksi- (Kor 섹 시-), which despite being adjectives in English become bound roots in Korean, ${ }^{24}$ from which hybrid nouns (cf. (4.1.8), (4.2.7)) can be derived. It is also worthy to note, that while seksinyeo (cf. (4.2.7)) has already become a dictionary entry, seksinam (cf. (4.1.8)) still has not.

(4.3) Derivatives with SK Suf-hwa (Kor -화, Chin -化) -ization/-ing

(4.3.1) 디지털화 dijiteolhwa-digitalization, [+], [SN], \{2006\}

(디지털 dijiteol-digital)

(4.3.2) 슬림화 seullimhwa-slimming, [+], [SN], \{2010\}

(슬림 seullim-slim),

(4.3.3) 데이터베이스화 deiteobeiseuhwa - the process of creating a database, $[+],[\mathrm{SN}],\{-\}$

(데 이터베이스 deiteobeiseu - a database).

New hybrid coinages with - $h w a$, forming concrete nouns in Korean are derived from borrowed adjectives (cf. (4.3.1)-(4.3.2)) or nouns (cf. (4.3.3)). As far as their structure is concerned they can be either simple words, derivatives or compounds in English (cf. (4.3.2), (4.3.1) and (4.3.3) respectively).

Apart from - $h w a$ other SK suffixes such as -gwang (Kor -광, Chin 狂) and -jang (Kor - 장, Chin 場) enable the nominification of LWs in Korean. The former denoting 'an enthusiast of $\mathrm{N}$ ' is attached either to concrete or abstract nouns and derives concrete nouns, as presented in the below (4.4). Structurally all nouns are simple words in English. The latter denoting 'a ground/ a place', as illustrated in (4.5), de-

${ }^{24}$ The DSK indicates that seksi- is a bound root of Koreanized adjective seksihada (Kor 섹 시하다). The Ministry of Culture, Sports and Tourism in the notification No. 1996-13 encourages to use its NK equivalent - santteuthada (Kor 산뜻하다) (cf. https://opendic.korean.go.kr/dictionary/view?sense_no= 196252\&viewType=confirm accessed 2020-04-05). 
rives concrete nouns regardless of their word-formative structure or abstract/ concrete meaning in English.

(4.4) Derivatives with SK Suf-gwang (Kor -광, Chin 狂) 'an enthusiast of N'

(4.4.1) 커피광 keopigwang - a coffee enthusiast, [+], [SN], \{2000\}

(커피 keopi-coffee),

(4.4.2) 댄스광 daenseugwang - a dance maniac, [+], [SN], \{2009\}

(댄스 daenseu-dance),

(4.4.3) 파티광 patigwang - a party maniac, 'party animal', [+], [SN], $\{2016\}$

(파티 pati - a party),

(4.4.4) 골프광 golpeugwang - a golf maniac, [-], [-], \{-\}

(골 프 golpeu - golf),

(4.4.5) 게임 광 geimgwang-a game maniac, $[-],[-],\{-\}$

(게임 geim - a game).

(4.5) Derivatives with SK Suf-jang (Kor - 장, Chin 場) 'a ground/ a place'

(4.5.1) 캠핑장 kaempingjang - a campground, a camping ground, [+], [SN], $\{2002\}$

(캠핑 kaemping - camping),

(4.5.2) 보드게임장 bodeugeimjang - a board game room/ place, [+], [SN], $\{2002\}$

(보드게임 bodeugeim - a board game). ${ }^{25}$

(4.6) Derivatives with other suffixes of both SK and NK origin

(4.6.1) 센터장 senteojang - the director of a center, [+], [SN], \{2011\}

(센터 senteo - a center + SK Suf -jang (Kor -장, Chin 長) - a person in charge),

(4.6.2) 패션가 paesyeonga - 'a fashion street', a street with fashion clothing stores $[+],[\mathrm{SN}],\{-\}$

\footnotetext{
${ }^{25}$ Apart from these examples there is a group of nouns derived from foreign words with the suffix -jang, which entered the Korean lexicon before 2000. Choo \& O'Grady in their 'Handbook of Korean Vocabulary' published in 1996 (p. 196) list the following nouns: (i) 골 프장 golpeujang - a golf course, $[+],[\mathrm{SN}],\{-\}$; (ii) 스케 이트장 seukeiteujang - a skating rink, $[+],[\mathrm{SN}],\{-\}$; (iii) 스키장 seukijang - a skiing ground; and (iv) 볼링장 bollingjang - a bowling alley. The DSK notes also 롤라스케 이트장 rollaseukeiteujang - a roller skating rink, [+], [SN], \{1992\} and 게임장 geimjang - a game ground, [+], [SN], \{1999\}. Nonetheless, Choo \& O'Grady treat these coinages as compounds, which is the result of taking SK Suf as a base since in Chinese it conveys the meaning of a 'ground, place'. In Korean word-formation however -jang is a bound form treated as a derivational suffix (cf. https://opendic.korean.go.kr/dictionary/view?sense_no= 259475\&viewType=confirm accessed 2019-11-20). That is why, in this research following Korean linguists and the DSK, coinages with -jang will be perceived as derivatives. Nonetheless, leaving the differences concerning their structural analysis aside, the existence of these examples confirms that LWs were used to derive nouns before the 2000s.
} 
(패션 paesyeon - fashion + SK Suf -ga (Kor -가, Chin 街) - a street),

(4.6.3) 센 스쟁 이 senseujaengi-a sensible person, [+], [SN], \{2006\}

(센스 senseu - sense + NK Suf -jaengi (Kor -쟁 이) - somebody who has a lot of attributes indicated by the root),

(4.6.4) 큐트쟁 이 kyuteujaengi-a cutie, [-], [-], \{-\}

(큐트 kyuteu - cute + NK Suf-jaengi (Kor -쟁 이) - (cf. 4.6.3)

(4.6.5) 쇼핑객 syopinggaeg - a customer, [+], [-], $\{-\}$

(쇼핑 syoping - shopping + SK Suf -gaeg (Kor -객, Chin 客) - a guest),

(4.6.6) 캡처꾼 kaepcheokkun - a person, who enjoys publishing on the Internet weird and funny expressions/ poses etc. made by celebrities, $[+],[\mathrm{SN}],\{2005\}$

(캡처 kaepcheo - capture + NK Suf-kkun (Kor -꾼) - a person notorious/ noted for doing something, a man occupied with something),

(4.6.7) 카메라발 kamerabal - the effect of pictures taken with a camera, which look more beautiful than the actual objects, [+], [SN], $\{2011\}$

(카메라 kamera - a camera + NK Suf-bal (Kor -발) - an effect).

Apart from the above-mentioned suffixal hybrid derivatives there are also examples confirming the existence of prefixal derivation. Nonetheless, prefixes are rather rarely attached to Koreanized LWs and thus are difficult to come by in comparison with suffixes. Prefixal derivatives are coined with few prefixes such as SK Pref saeng- (Kor 생 -, Chin 生) conveying the meaning of 'raw/ unprocessed'. As illustrated in (4.7) saeng- is attached either to concrete or abstract nouns and derives both kinds of nouns depending on the semantic properties of the base.

(4.7) Prefixal derivatives with SK Pref saeng- (Kor 생-, Chin 生) 'raw/ unprocessed'

(4.7.1) 생데 이터 saengdeiteo - raw data, [+], [SN], \{-\}

(데 이터 deiteo - data),

(4.7.2) 생미사 saengmisa - Holy Mass for the living ones, [+], [SN], $\{-\}$

(미사 $m i s a-$ Holy Mass),

(4.7.3) 생이스트 saengiseuteu - fresh yeast, [+], [SN], \{2003\}

(이스트iseuteu - yeast),

(4.7.4) 생소시지 saengsosiji-a fresh sausage, [+], [SN], $\{2010\}$

(소시지 sosiji-a sausage),

(4.7.5) 생슬러지 saengseulleoji-a raw sludge, [+], [SN], \{-\}

(슬러지 seulleoji-sludge). 
(4.8) Prefixal derivatives with other prefixes

(4.8.1) 시월드 siwoldeu - one's husbands family (in-laws), [+], [SN], $\{2012\}$

(SK Pref 시- si (Chin 媤) - one's husbands family (in-laws) + 월드 woldeu - world),

(4.8.2) 비매너남 bimaeneonam - an ill-mannered man, [+], [SN], \{2014\} (SK Pref bi- (Kor 비-, Chin 非) non-/ un- + 매너 maeneo - (a) manner(s) + SK Suf-nam (Kor - 남, Chin - 男) - a male),

(4.8.3) 초슬림화 choseullimhwa-ultra slimming, [+], [SN], \{2010\} (SK Pref cho- (Kor 초-, Chin 超) ultra-/ super- + 슬림 seullim $-\operatorname{slim}+$ SK Suf_hwa (Kor -화, Chin -化) -ization).

Among the prefixal hybrid derivatives illustrated in the above (4.8) are prefixal derivatives (cf. (4.8.1)) and prefixal-suffixal derivatives (cf. (4.8.2)-(4.8.3)). The latter can in fact be called hybrid string derivatives ${ }^{26}$ and so can be the examples given at the below (4.9). Although there is a structural difference between examples given at (4.8) and (4.9)-(4.10), yet in both cases a derivative was 'enriched' with a suffix. Hybrid string derivatives in question, which are verb derivatives here, are derived from already existing noun derivatives with the help of already-mentioned and widely used NK Suf - hada (Kor -하다) and -doeda (Kor -되다). The later conveys the meaning of 'to become/ get/ be N'. Their existence confirms a relatively wide use of LWs in the word-formation and the growth of their social acceptance. Consider the following examples:

(4.9) String derivatives with SK Suf-hada (Kor -하다)

(4.9.1) 슬림화하다 seullimhwahada - to make a scale or volume small, [+], [SN], \{2000\} (슬림화 seullimhwa-slimming, cf. (4.3.2)),

(4.9.2) 디지털화하다 dijiteolhwahada-to digitalize, [+], [SN], \{2000\} (디지털화 dijiteolhwa - digitalization, cf. (4.3.1)).

(4.10) String derivatives with SK Suf-doeda (Kor -되다)

(4.10.1) 슬림화되다 seullimhwadoeda - to become slim (about the scale or volume), [+], [SN], \{2002\}

(슬림화 seullimhwa - slimming, cf. (4.3.2) and (4.9.1)),

\footnotetext{
${ }^{26}$ This term was coined by the author of this research in order to indicate a word derived from already existing derivative as an analogical term to 'a string compound' (Kor 연 쇄 합성어, yeonswae hapseongeo), used in the Korean word-formation field by Choe (1993), Lee (2000) and many others. Furthermore, Korean linguists to indicate prefixal-suffixal derivatives use the term 'both-sided/ two-sided derivative' (Kor 양면 파생어, yangmeon pasaengeo), while Plag (2003: 38) uses the term 'multiple affixation' and refers to the process of 'simultaneous multiple affixation' as parasynthesis. Nonetheless, since it is clear in case of the above examples (4.8) which derivative - the prefixal or suffixal one was coined as first, and in case of the suffixal derivatives (4.9)-(4.10) which one was derived as first - calling both types 'string derivatives', according to the author's humble opinion, appears to be justified and right.
} 
(4.10.2) 디지털화되다 dijiteolhwadoeda - to be digitalized, [+], [SN], $\{2002\}$

(디지털화 dijiteolhwa - digitalization cf. (4.3.1) and (4.9.2)).

Furthermore, hybrid derivatives are also used in compounds, which is also worth mentioning here. Derivatives coming from 'camping' (Kor 캠핑, kaemping) and 'skating' or 'skates' (Kor 스케이트 seukeiteu) derived with SK Suf-jang (Kor -장, Chin 場) meaning 'a ground' or 'a place', and indicating 'a camping ground' (cf. (4.5.1) 캠 핑장 kaempingjang) and 'skating rink' (Kor 스케이트장, seukeiteujang) respectively can serve as examples here.

(4.11) Hybrid derivatives as a part of hybrid compounds

(4.11.1) 오토캠 핑장 otokaempingjang - an auto-camping site, [+], [SN], $\{2004\}$,

(4.11.2) 인라인스케이트장 inlainseukeiteujang - an in-line skating ring, $[+],[\mathrm{SN}],\{2000\}$,

(4.11.3) 실 내스케이트장 silnaeseukeiteujang - an indoor skating rink, [-], $[-],\{-\}$.

It is also worthy to note that for the sake of phonetic convenience lengthy LWs can be either borrowed in a shortened form (cf. (4.12)) or shortened in Korean (cf. (4.13)). In case of the latter they do not have English equivalents and thus are yet another example of Konglish. Among these formations are fore- and back-clippings, as illustrated below.

(4.12) Back-clippings having English equivalents

(4.12.1) 에어컨 eeokon - an aircon, [+], [SN], \{-\}

(from 에어컨 디셔너 eeokeondisyeoneo - an air conditioner)

(4.12.2) 콘도 kondeo - a condo, [+], [SN], \{-\},

(from 콘도미니엄 condominieom - a condominium),

(4.12.3) 마이크 maikeu - a mike [+], [SN], \{-\},

(from 마이크로폰 maikeuropon - a microphone),

(4.12.4) 프로 peuro - a pro, [+], [SN], \{-\}

(from 프로페셔 널 peuropesyeoneol-professional).

(4.13) Fore- and back-clippings being KG

(4.13.1) 멘트 ment (from announcement, Kor 어나운스먼트, eonaunseumeonteu $)$ - an announcement, [+], [NSN], $\{2001\}$, $^{27}$

\footnotetext{
${ }^{27}$ The NSN of ment suggests it can be written in another way. In fact, its full form is eonaunseumeonteu (Kor 어나운스먼트), which as the DKS notes is yet to be standardized (cf. https://opendic.ko rean.go.kr/search/searchResult?focus_name=query\&query=어나운스먼트 accessed 2019-11-19). Nonetheless, from this abbreviated form, the verb menteuhada (Kor. 멘트하다) meaning 'to announce' has already been derived.
} 
(4.13.2) 아마 ama (from amateur, Kor 아마추어, amachueo - an amateur $[+],[\mathrm{SN}],\{-\}$,

(4.13.3) 에로 ero (from erotic, Kor 에로틱 erotic) - erotic, [+], [SN], $\{-\}$,

(4.13.4) 애플 aepeul (from application, Kor 애플리케이션 aepeullikeisyeon) - an application, [+], [SN], \{2009\}.

As exemplified in the above (4.13) the Koreanized LWs can undergo clipping. Their clipped forms may also be used in derivation and compounding, which (4.14) and (4.15) illustrate. (4.14.1)-(4.14.2) are derived from alba (Kor 알바) - the abbreviated form of areubaiteu (Kor 아르바이트) meaning 'a part-time job' or 'a side job', while (4.14.3)-(4.14.4) have gem (Kor 겜) from geim (Kor 게임) - conveying the meaning of 'a game' as their base. The last example (4.14.5) is derived from the shortened form of camera (Kor 카메라) - that is kaem (Kor 캠) denoting 'a camera', despite the fact that its spelling is yet to be standardized.

(4.14) Clipped forms used in derivatives

(4.14.1) 알바남 albanam - a man who temporarily works a part-time job, $[+],[-],\{2014\}$

(4.14.2) 알바녀 albanyeo - a woman who temporarily works a part-time job $[+],[\mathrm{NSN}],\{2015\}$

(4.14.3) 겜 광 gemgwang - a game maniac, $[+],[-],\{2003\}$,

(4.14.4) 겜하다 gemhada - to play a (computer) game, [-], [-], $\{-\}$,

(4.14.5) 캠발 keambal - the effect of pictures taken with a camera, which look more beautiful than the actual objects, $[+],[\mathrm{SN}],\{2000\}$.

(4.15) Clipped forms used in compounds

(4.15.1) 아마골프 amagolpeu - an amateur golf, [+], [NSN], \{2004\},

(4.15.2) 아마골퍼 amagolpeo - an amateur golfer, [+], [NSN], \{2001\}.

Furthermore, some of the borrowings regardless of the existence of their abbreviated form in Korean had their shortened form borrowed as well. It is rather unlikely that 'app' (cf. (4.16.2)) was clipped in Korean.

애플리케이션 aepeullikeisyeon - an application, [+], [SN], \{-\}

(4.16.1) 애플 aepeul - an application, [+], [SN], \{2009\},

(4.16.2) 앱 aep - an app, [+], [SN], \{2010\}.

\section{Conclusions}

In the past, especially when the Joseon Dynasty (1392-1910) ruled Korea, the knowledge of Chinese characters was associated with elites and noble birth, it gave prestige, social respect and was downright mandatory for those, who wanted to suc- 
ceed and make a career. In present times the situation has changed though, and the privileged place for centuries occupied by the Chinese characters is now taken by English, which means that the good command of English opens the door to a career. The increase in the number of loans, most notably of English origin, is also the result of close relations between South Korea and the US commenced in the 1950 .

The globalization resulting in the formation of the 'Global Village' apart from economic, political and social aspects also has its lingual consequences, which as this article has shown, are rather difficult, if not impossible, to avoid. Since English is among the preferred languages in the world and has already established its position as a lingua franca, it is not a surprise that it has the biggest influence on the youngest but rapidly expanding sub-lexicon of the Korean language, namely the hybrid sub-lexicon.

However, the formation of various kinds of hybrids - either the hybrid derivatives or hybrid compounds would not be possible if the numerous borrowings coming from various semantic fields have not been initially incorporated to the Korean lexicon. Using LWs in derivation in Contemporary Korean confirms a relatively great advancement in the above-mentioned language integration and foreshadows further changes to the Korean lexicon such as borrowing affixes or even wordformation patters such as acronymization and reanalysis, examples of which are already present in Korean. Nonetheless, it also confirms the growth of social acceptance concerning their usage as well. While borrowing from other languages due to the lack of lingual equivalents is perceived as something almost natural and unavoidable, using foreign elements such as bases and affixes, or word-formation patterns, is not. The growing hybridization of the Korean lexicon also shows the enormous creativity of Konglish coiners, the majority of which are young Koreans, who play with the language most creatively and freely.

There are basically two types of hybrid derivatives in Korean, which can be coined from:

(i) a base of foreign provenance and a NK or SK affix, or

(ii) a NK or SK base and a foreign affix.

This article though, focusing only on the first type, identified and exemplified:

(i) the adjectivization and verbification, and

(ii) the nominification of the LWs achieved with the help of SK or NK suffixes.

Despite the fact that nouns are derived with various suffixes and prefixes, unlike adjectives and verbs generally derived with NK Suf-hada, the productiveness of -hada makes these hybrid derivatives very popular in various aspect of social and professional life. The research also referred to the so-called 'string derivatives', and 
addressed the question regarding the usage of clipped LWs in both derivation and compounding, which also results in 'enriching' the hybrid sub-lexicon of Contemporary Korean.

Some of the presented examples may be perceived as nonce formations coined in a spur of the moment by the younger generations of Koreans, and thus may not be known and widely used by the general public - especially the older generation. Nonetheless, some of them have already become dictionary entries. Considering the above, one may assume that they constitute rather small number of hybrid formations and thus have rather minor effect on word-formation tendencies in Contemporary Korean. However, bearing in mind that some of them are already noted in dictionaries and that the young generation will sooner or later decide about the national language policy, the Korean language purists have few reasons to fear about. As regards to the Korean language not only the excessive use of LWs is worrying, but also the use of previously not observable word formation patterns and affixes of foreign provenance. For the time being the new hybrid coinages, may be not that numerous in comparison to the rest of lexemes constituting the lexicon of the Korean language, but their number is springing up like mushrooms after the rain. In a longer perspective this tendency may foreshadow further even more prominent changes, that might be difficult to overturn if not identified and prevented from happening in time. The protection of the national language is especially important since it is one of the determinants of national identity with which every nation identifies itself and which stores its cultural and material values, and a specific way of perceiving the world.

The question concerning the growing presence of hybridization in the lexicon of Contemporary Korean deserves a more comprehensive study. Given the fact that the number of hybrid derivatives and hybrid compounds is raising at high speed - the author is planning to continue this research in foreseeable future.

\section{References}

Bańczerowski, J. 2001. "The linguistic legacy of Ludwik Zabrocki”. In: Puppel, S. (ed.). The Ludwik Zabrocki Memorial Lecture. Poznań: Wydział Neofilologii UAM. 8-49.

Bauer, L. 1983. English word-formation. Cambridge Textbooks in Linguistics. Cambridge: Cambridge University Press.

Bernard, R. 2004. "Inflexion and derivation". In: Strazny, P. (ed.). Encyclopedia of Linguistics. London/New York: Routledge. 529-530.

Bird Bishop, E. 1897. Korea and her neighbors. Seoul: Yonsei University Press.

Bloomfield, L. 1933. Language. London: Ruskin House, George Allen and Unwin, Ltd.

Borowiak, A. 2015. "On some selected problems of Korean abbreviology". International Korean Journal of Humanities and Social Sciences 1. 137-164.

Borowiak, A. 2016. "On some properties of acronyms used in Korean". International Korean Journal of Humanities and Social Sciences 2. 123-155. 
Borowiak, A. 2019. "Growing influence of hybridization on neologisms in contemporary Korean". The $8^{\text {th }}$ International Conference of Oriental Studies - Challenges of Interdisciplinary and Multidisciplinary Approach, PAN-UW, Warsaw, 25-26 Nov. 2019.

Choe, Sang Jin (최상진). 1993. 연쇄 합성어의 어휘 형성에 대하여, [in:] 어문논총, 제8집, 경희 대학교 국어국문학과. 47-63.

Choo, Miho and Kwak, Hye-young. 2008. Using Korean - A guide to contemporary usage. Cambridge: Cambridge University Press.

Choo, Miho and w. O'Grady. 1996. Handbook of Korean vocabulary - A resource for word recognition and comprehension. Seoul: 한국문화사.

Connor, M. 2009. Asia in focus - The Koreas. Santa Barbara, CA: ABC-CLIO, LLC.

Dressler, W.U. and M. Kilani-Schoch. 2016. "Natural morphology". In: Hippisley A. and G. Stump (eds.). The Cambridge Handbook of Morphology. Cambridge Textbooks in Language and Linguistics. Cambridge: Cambridge University Press. 356-389.

Dressler, W.U. 2005. "Towards a natural morphology of compounding". Linguistica 45.2. 29-40.

Elliot Griffis, W. 1894. Corea: The Hermit nation. New York: Charles Scribner's Sons.

Hamans, C. 2015. "Global language contact". In: P. Chruszczewski. (ed.). Languages in contact 2014. Wrocław-Washington D.C.: Wydawnictwo Wyższej Szkoły Filologicznej we Wrocławiu. 159-181.

Hamans, C., Fisiak, J. and E.H. Jahr. 2009. "Degrammaticalization and reanalysis". European Parliament, Brussels/ Strasbourg, Adam Mickiewicz University in Poznań. Kristiansand: Uniersity of Adger. 145-167.

Haspelmath, M. 1995. "The growth of affixes in morphological reanalysis". In: Booij, G. and J. Marle. (eds.). Yearbook of morphology 1994. Dordrecht: Kluwer Academic Papers. 1-29.

Huszcza, R. 2011. "Wschodnioazjatycki krąg cywilizacji pisma - lingwistyczna analiza pojęcia". In: L. Sudyka (ed.). Orientalia Commemorativa. Kraków: Wydawnictwo Uniwersytetu Jagielońskiego. $115-132$.

Jeon, Myeong-mi (전명미), Choi Dong Ju (최동주). 2007. 신어의 단어 형성법 연구 - 2002·2003·2004 신어를 대상으로-, [in:] 한민족어문학, 제50집, 한민족어문학회, pp. 37-70.

Kang, Hee-suk (강희숙). 2016. 한국어 어문 규정의 이해, 서울: 연락.

Kastovsky, D. 1977. "Word-formation, or: at the crossroads of morphology, syntax, semantics and the lexicon". Folia Linguistica 10.1-2. 1-33.

Kastovsky, D. 1982. "Word-formation: a functional view". Folia Linguistica 16.1-4. 181-198.

Kim, Chang-sop (김창섭). 1996. 국어의 단어 형성과 단어 구조 연구, 국어학 총서 21, 서울: 태학사.

Kim, Chang-sop (김창섭). 2008. 한국어 형태론 연구, 서울: 태학사.

Kim, Jung-nam (김정남). 2005. 국어 형용사의 연구, 서울: 도서출판 연락.

Kim, Kwang Hae (김광해), Kwon Jae-il (권재일), Lim Ji-ryong (임지룡), et al. 1999. 국어 지식 탐구, 서울: 도서출판 박이정.

Kim, Seung Gon (김승곤). 2009. 21 세기 우리말본 연구, 국어학총서 · 문법론, 서울: 도서출판 경진문화.

Ko, Jong-suk (고종석). 2014. 감연된 언어 - 국어의 변두리를 담은 몆 개의 풍경화, 고양시: 개마고원.

Koh, Jae Sol (고재설). 1999. 동사 ‘-하'와 형용사 ‘-하', [in:] 언어학, 제4권, 대한언어학회. 25-45.

Lee, Hyeon Gyu (이현규). 1983. 국어형태구조의 사적 연구-접미사「-하다」, 「-답다」를 중심으로-, [in:] 언어학, 제43호, 한국어문학회. 155-188.

Lee, Kwang-ho (이광호). 2009. 국어 파생 접사의 생산성 저지에 대한 계량적 연구, 국어학 총서 65 , 서울: 태학사.

Lee, Nam-suk (이남숙). 2000. 국어 연쇄 합성어 어휘 형성에 관한 연구, 慶熙大學校大學院: 國語 國文學科, 석사학위논문. 
Lim Ji-ryong (임지룡), Lee Eun-kyu (이은규), Kim Jong-rok (김종록) et al. 2005. 학교문법과 문법교육, 서울: 도서출판 박이정.

Lim, Hong-bin (임홍빈). 1996. 외래어 표기의 역사, [in:] 새국어생활, 제 6권, 4호. 3-40.

Mattiello, E. 2013. Extra-grammatical morphology in English - abbreviations, blends, reduplicatives and related phenomena. Topics in English Linguistics 82, Berlin/Boston: De Gruyter Mouton.

National Institute of Korean Language, Dictionary of Standard Korean https://opendict.korean.go.kr /main (accessed 2019-03-21).

Plag, I. 2003. English word-formation. Cambridge Textbooks in Linguistics. Cambridge: Cambridge University Press.

Puppel, S. 2017. ECOLI[S] ${ }^{2}$. Essays and notes on ecolinguistic synergy and synthesis. Scripta de Communicatione Posnaniensi, Prace Naukowe Katedry Ekokomunikacji UAM, Vol. 8, Poznań: Wyd. UAM.

Shim, Jae-kee (심재기). 1982. 국어 어휘론, 서울: 집문당.

Sohn, Ho-Min. 2001. The Korean language. Cambridge: Cambridge University Press.

Song, Jae Jung. 2005. The Korean language: structure, use and context. London/New York: Routledge.

Szymanek, B. 2012. Introduction to morphological analysis. Warszawa: Wydawnictwo Naukowe PWN.

Weinreich, U. 1953. Languages in contact, findings and problems. New York: Publications of the Linguistic Circle of New York.

Zabrocki, L. 1963. Wspólnoty komunikatywne w genezie i rozwoju języka niemieckiego. Część I-Prehistoria języka niemieckiego. Wrocław-Warszawa-Kraków: Zakład Narodowy im. Ossolińskich.

Zabrocki, L. 1980. „Phonologie und distinktive Morphologie”. In: Bańczerowski, J. (ed.). U podstaw struktury i rozwoju języka/ At the foundation of language structure and development. WarszawaPoznań: PWN. 105-112. 